\title{
ROBOGUIDE 3D-s SZIMULÁCIÓS RENDSZER BEMUTATÁSA ÉS ELEMZÉSE
}

\section{ROBOGUIDE 3D SIMULATION'S SYSTEM INTRODUCING AND ANALYSING}

\author{
Leite Clayton Frederick Souza ${ }^{1}$, Cavalcanti Marília Cordeiro ${ }^{2}$ \\ ${ }^{1}$ Universidade Federal de Pernambuco - Centro de Tecnologia e Geociências; \\ Brasil, Recife, Rua Av. da Arquitetura, s/n', CEP 50740-550; Telephone: +36-30- \\ 5451206; clayton.frederick@gmail.com \\ ${ }^{2}$ Universidade Federal de Pernambuco - Centro de Tecnologia e Geociências; \\ Brasil, Recife, Rua Av. da Arquitetura, s/n', CEP 50740-550; Telephone: +36-30- \\ 5451181; lila_cordeiro18@hotmail.com
}

\begin{abstract}
This paper introduces the FANUC's ROBOGUIDE which is a family of robot simulation software products whose purpose is to assist engineers in designing, programming and testing robot processes in a $3 \mathrm{D}$ environment without the need of developing a prototype work cell. It shall be described the both methods for producing a simulation in this software along with its characteristics such as the basic commands, common bugs, possibilities and relations with the real life robot programming in industries. Some examples are also depicted in this work.
\end{abstract}

Keywords: Roboguide, teach pendant, 3D Simulation

\section{Összefoglalás}

Ebben a cikkben a FANUC cég, ROBOGUIDE nevü 3D-s szimulációs rendszerét mutatjuk be és elemezzük. A szimulációs rendszer célja a mérnöki tervezés segítése, úgy a programozásban, mint a robotcella megtervezésében, és későbbiekben a folyamat elemzésében. A szimulációs rendszerek nagy előnye, hogy a költséges prototípus-cella legyártása nélkül is bizonyos folyamatok elemzésére és alapvető hibák elkerülésére nyújt lehetőséget. Továbbá, megemlítésre kerül a szimulációs rendszer kétfajta programozási lehetősége (betanitó panelen keresztüli programozás, és az 'off-line' programozás), és mindezek mellett megemlítésre kerülnek a rendszerrel kapcsolatos jellegzetességek (előnyök, hátrányok). A cikkben az egyes szituációk példákkal lesznek alátámasztva.

Kulcsszavak: roboguide, betanitó panel, 3D-szimuláció.

\section{Introduction to the Roboguide software}

Designing, programming and testing robot processes in real life can be quite difficult, expensive, time demanding and troublesome. For this reason, there are some computer applications which give the possibility to virtually create complex and sophisticated robot processes by providing the user with solid simulation tools; for example, the FANUC's ROBOGUIDE family of robot simulation software 
products. With this software, it's also possible to observe the operation and performance in animated simulation, to evaluate cycle times and reach as well as to check for possible interferences between the robot and other objects. And one important feature of the software is that the interface is easy and intuitive when creating a virtual work cell, so special skills for this are not required.

The Simulation Program and the Teach Pendant are the two methods available for simulating robot programs in the software environment and shall be discussed here.

\section{Task}

The given task consists in presenting the Simulation Program method by introducing the program interface, describing the basic commands possible to implement and revealing the common bugs present which makes the use of this method troublesome in certain occasions. Also the Teach Pendant method shall be discussed, exemplified and presented its relation to the real life robot programming.

\section{The Simulation Program}

The Simulation Program represents the off-line programming mode for developing the process which a given work cell should perform and it consists of adding commands as simple as moving from one position to another, waiting for a set time, picking up an object and dropping it. The user is able to import CAD models of parts, machines tools and work cells, so the environment can be practically identical to the real situation.

The interface is friendly without any further difficulty when using the software, and it is possible to visualize the work envelope which determines the area where the robot can actually work. When two or more robots are working with a common part, it is necessary to make sure that the work envelope of both robots share a common area.

\subsection{Basic commands}

\subsubsection{Position}

This command is used to create paths to be followed, the movement itself of the robot. Once the user records position P1, by setting up its coordinates in the work place, and then records a different position P2, the software will create a path from P1 to P2.

\subsubsection{Wait command}

It will create a delay which the robot should wait until executing the next command.

\subsubsection{Pickup command}

As its name says, it will pick up a part from a certain fixture by using the robot tool, such as a gripper, for instance.

\subsubsection{Drop Command}

The drop command will allow a part to be dropped from the robot tool onto a fixture.

\subsection{Bugs}

\subsubsection{Gripper position}

When a gripper is added to the robot its position is turned from $90^{\circ}$. To fix that, the user must change the tool's properties.

\subsubsection{Pickup / Drop}

Another bug of this software happens when the user tries to simulate the pickup from a fixture and the drop of this part on the same fixture. Instead of the part staying in the final position, it will automatically come back to the initial position after the drop command.

To fix that, the user must create a second fixture which visibility will be set to transparent and then place it exactly over the first fixture. This way, there will be 
different places for the pickup and drop command.

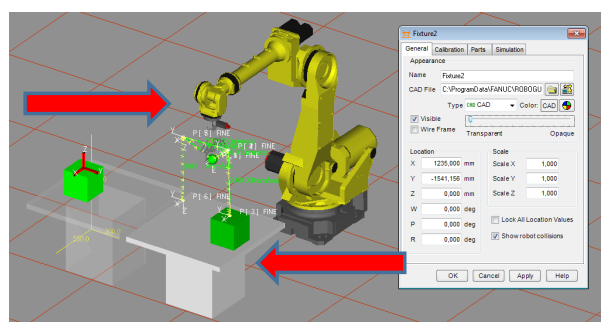

Figure 1. Setting the visibility for pickup and drop of a part on the same fixture.

\section{The Teach Pendant}

\subsection{The device}

Teach pendants are handheld devices used in industrial applications to program and control robots in performing a specific task. In order to create a program using the teach pendant, the operator makes use of its buttons and switches to provide the robot with information about position, speed, delays and other specific functions such as the opening and closing of a gripper. It is also possible to create more complex programs since the teach pendant can handle digital and analog inputs and outputs, execute conditional jumps as well as store temporary data in registers.

The FANUC's Roboguide HandlingPRO software is provided with a Teach Pendant tool which can be used to simulate the programming of the robots in the software's 3D space.

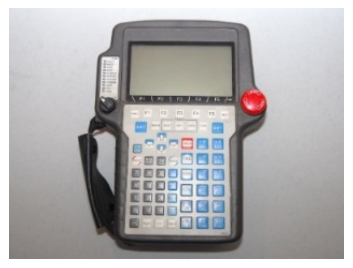

Figure 2. An actual Teach Pendant

\subsection{An example program}

The figure 3 shows a robot, a box, a conveyor and a cart. In the simulation, a conveyor carries the box to a certain position where the robot should pick it up and place it onto the cart. In the figure, it is showed the first steps the robot should take. Firstly, the robot should get to an initial position and following this the Teach Pendant sends an ON signal to the conveyor motor which is switched to OFF after a Wait command of 1.3 seconds. The robot should then approach the box to pick it up.

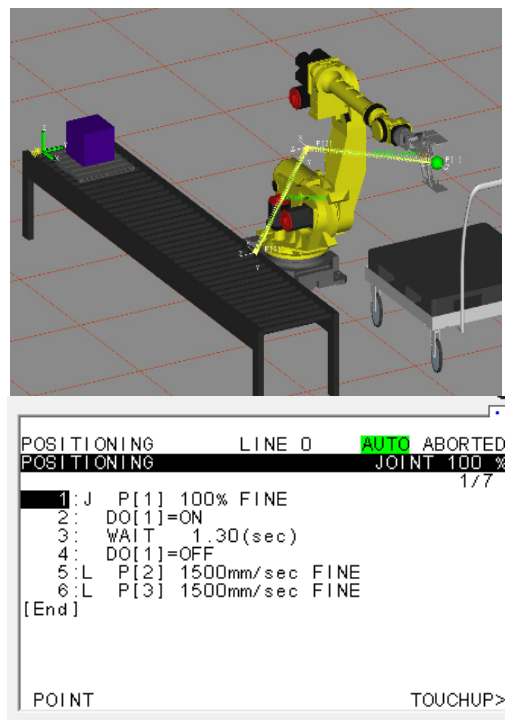

Figure 3. Example of Teach Pendant program

However the pickup action should be performed by the Simulation Program, since the Teach Pendant method on the software can't actually simulate the physics of holding a box - that means, the friction forces involved in this action - by only the closing of the gripper. That leads to the use of the Teach Pendant and the Simulation Program together.

Programs created on the Teach Pendant are called as macros into the Simulation Program and intercalated with the pickup and drop actions. The macros for carrying the box and getting back to the original position are created similarly as the positioning macro. 
1: CALL POSITIONING

2: Pickup ('Part1') From ('Machine1:Link1') With ('GP: 1 - UT: 1 (Eoat1)')

3: CALL CARRYING

4: Drop ('Part1') From ('GP: 1 - UT: 1 (Eoat1)') On ('Fixture1')

5: CALL QBACK -

Figure 4. The use of the Simulation Program with Teach Pendant macros

\section{Conclusion}

For its simplicity, accuracy and similarity to the real life conditions of application, this software represents a powerful tool. Its uses for educational purpose may increase the interest of those who want to learn about robot control programming, while in the industrial field, its potential to test and optimize programs before implementation represents a great improvement to this field. However it has some issues or bugs which have to be fixed before it can guarantee the best experience for the engineer in the industrial area.

\section{Acknowledgements}

The authors express their gratitude for CAPES (Coordenação de Aperfeiçoamento de Pessoal de Nível Superior) and the Science without Borders program for the scholarship granted under process number 88888.056975/2013-00 and $88888.058539 / 2013-00$. The project was also assisted by the European Union, with the co-financing of the European Social Fund, TÁMOP-4.1.1.C-12/1/KONV-20120002 . This work was also sponsored by the Hungarian National Scientific Fund (OTKA 105846).

\section{References}

[1] Nagy, I., Bencsik, A.L.: A Simulation System for Behaviour-based Potential Field Building in Multi-agent Mobile Robot System, Proc. of $3^{\text {rd }}$ Int. Conf. IAESTED, Canada, Banf, 2007, 7-12.

[2] FANUC Robotics Ibérica S.L.: Robótica Programación FANUC.

[3] Werner Schollenberger: Accompanying Training Manual. FANUC Robotics Deutschland GmbH. 